\title{
Seroprevalence and molecular detection of Bovine Parainfluenza-3 Virus (BPI-3V)
}

\author{
Lina Shaheed AL-abudy Mohsen Abed Nema Alrodhan \\ Coll. of Vet. Med./ Univ. of Al-Qadisiya \\ email: Linasha2014@yahoo.com \\ (Received 30 September 2013, Accepted 3 November 2013)
}

\begin{abstract}
The study aims to investigation the presence of Bovine Parainfluenza-3 Virus (BPI-3V) by using direct Enzyme Linked Immunosorbent Assay (ELISA) and Real Time- quantitative Polymerase Chain Reaction RT-qPCR technique and evaluation some clinical and epidemiological features of the disease. One hundred forty seven (147) animals of different age (6 months to 8 years) and sex from different regions of Al-Diwaniya governorate that showed respiratory signs were examined between November 2012 and April 2013. Results of clinical study showed that there was increase in body temperature up to $40 \mathrm{C}^{0}$, serous watery nasal discharge, increase respiratory rate, abnormal breath sound (loud, harsh sound, whistling or wheezing), and coughing. The infection rate by using direct ELISA test was (30.26\%). The spreading rate of BPIV-3 in relation to ages, regions and months of the years was (48\%) in age group 6 months-3 years, highest rate $(60 \%)$ in December as compare with other months and Sedeer region recorded infection rate (40\%). The results of Real Time-qPCR showed high infection rate of BPI-3 virus $55.13 \%$ in cattle population as high sensitivity of this technique. Higher percentage recorded in tracheal tissue sample $60.60 \%$ as compare with lungs tissue and nasal swabs in percentage $54.54 \%$ and $50 \%$, respectively. In conclusion there was a characteristic epidemiological feature of spreading of BPIV-3 in depending on age groups, different regions, and different months of the year.
\end{abstract}

Key words: BPIV-3, seroprevalence and molecular detection, (BPI-3V) antigens, clinical and epidemiological features of (BPI-3V) .

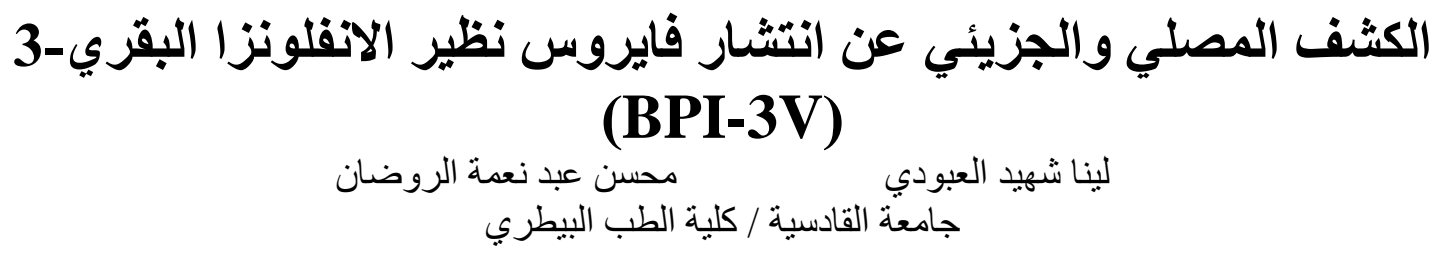

الخلاصة

تهدف الدراسة الى التحري عن وجود فايروس نظير الأنفلونزا البقري BPI-3 باستخدام فحص المقايسة المناعي

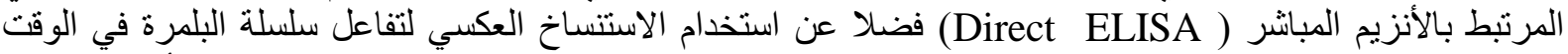
الحقيقي

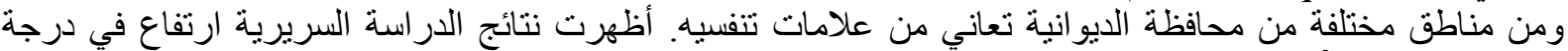

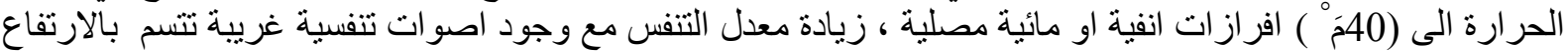
و الخشونة مع وجود الصفير في بعض الحالات ـ ان نسبة الخمج باستخدام فحص الاليز الكانت (

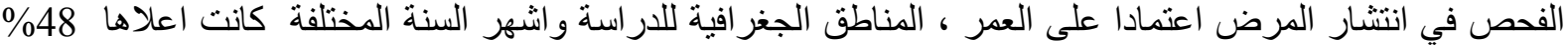

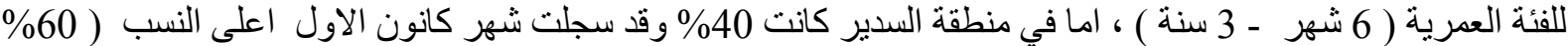

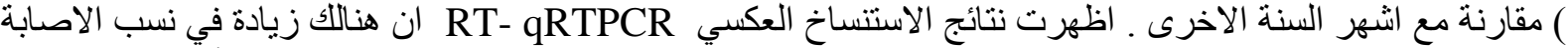

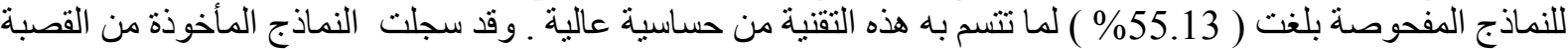

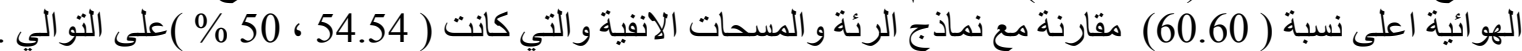

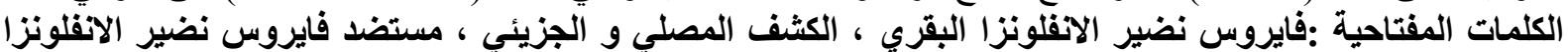

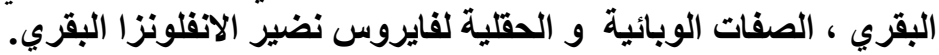




\section{Introduction}

Paramyxoviruses are well known pathogens of the central nervous and respiratory system of many host species. In the last few decades, many novel paramyxoviruses have emerged causing devastating illnesses in different aquatic and terrestrial animals, including in some cases a species jump to humans (1).Bovine Parainfluenza type 3 virus (BPIV-3) infection constitutes a primary component of shipping fever complex in cattle and small ruminants characterized by pneumonia and upper respiratory tract symptoms. This virus infection appears to be most important in calves under stress due to weaning, shipping, and nutritional changes(2,3). Clinical disease is most common in calves with poor passive transfer or decayed maternal antibodies. It is usually mild, consisting of fever, nasal discharge, and dry cough $(4,5) . B P I V-3$ is a primary agent of bovine shipping fever worldwide (6) and it is the most common virus infection of respiratory tract of cattle (7). Sometimes cause severe disease as single agent, also it can predispose the animal to bacterial infections as the second invaders to worsen the ill-animal's condition(8). Most cases of respiratory infection with BPIV-3 occur with mild clinical signs but more severe infection may be associated with bacterial or virus agents (9). Parainfluenza type 3 virus is one of the clinical disease syndromes in bovine respiratory disease complex, it causes epithelial damage inducing bacterial invasion e.g (Manheimia spp.) infections in infected cattle (10).

\section{Materials and methods}

Clinical examinations: The clinical examination of infected animals with respiratory signs was recorded in application form which was included body temperature, respiratory system examination, and gross examination of lung, trachea, and bronchi.

Samples collection: This study was carried out between November 2012 and April 2013 by examination of (147) animal that showed respiratory signs in different age (6 months 8 years) and sex from different regions of the governorate. blood samples were collected from clinical cases and normal cattle, nasal swab samples were collected from clinical cases, and tissue samples were collected from slaughtered cattle as follow. Nasal swabs: Twenty eight nasal swab samples were collected by using sterile cotton swab. each swab sample was mixed with $1 \mathrm{ml}$ of phosphate buffer saline. The samples were transferred as soon as to the laboratory by cooled box. Serum samples: Eighty six blood samples $(5 \mathrm{ml})$ were collected by using sterile disposable syringes and blood container. After disinfection skin site of the jugular vein region by using cotton and $70 \%$ of ethyl alcohol. The collected blood is transported by cooled box to the laboratory and then the cleared serum were separated by centrifugation at (3000 rpm) for 10 minutes, the aliquots were transferred into sterile microtube $1.5 \mathrm{~mL}$ (eppendrof), and were kept frozen at- $20^{\circ}$. Tissue samples: Tissues samples from 33 lung and 33 trachea were collected from slaughter house in AlDiwaniya city by using sterile scissor and artery forces by incision sample piece and placed into sterile disposable container with PBS, then all samples transported to the laboratory by cooled box and storage at -20 ${ }^{0}$ C. Serological assay: Direct ELISA kit developed by (ABO) Switzerland was used to determine the presence of Bovine parainfluenza-3 Virus. The sample has been added to the bottom of ELISA plates coated well, the plate was incubated for $30 \mathrm{~min}$ at $37^{\circ} \mathrm{C}$. The reaction stopped by adding stop solution $(50 \mu \mathrm{L})$ to each well, ( the blue color was changed to yellow color) reading the absorbance at $450 \mathrm{~nm}$ after adding stop solution and within $15 \mathrm{~min}$. The result of samples was calculated according to kit protocol by: Cut off $=(+v e+-v e) / 2=$ if the result $\leq 0.5$ it conceder negative, while the positive results is $\geq 0.5$.

Molecular study : The molecular study was performed for detection of Bovine Parainfluenza virus 3 in nasal swab samples, lung, and tracheal tissues samples of clinically suspected cattle with BPIV-3 by 
using one step Real-time qPCR kit (Bioneer/Korea) according to method described by Thonur (11). Primers and Probe were designed by this study using specific sequence of nucleocapsid protein $(\mathrm{Np}$ gene of Bovine Parainfluenza virus 3)from NCBIGen Bank Data base and Primer3 online.(Bioneer company, Korea). Table(1)

Table (1): primers and probe used for molecular diagnosis:

\begin{tabular}{|c|c|c|c|}
\hline Primer & \multicolumn{2}{|c|}{ Sequence } & $\begin{array}{c}\text { Product } \\
\text { size }\end{array}$ \\
\hline \multirow{2}{*}{$\begin{array}{c}\text { BRV (VP6) } \\
\text { primer }\end{array}$} & $\mathrm{F}$ & $\begin{array}{c}\text { ACTCAGCGTCAT } \\
\text { TCACACTG }\end{array}$ & \multirow{2}{*}{$84 \mathrm{bp}$} \\
\cline { 2 - 3 } & $\mathrm{R}$ & $\begin{array}{c}\text { TTTCTGATCCCGC } \\
\text { ATTGAGC }\end{array}$ & \\
\hline $\begin{array}{c}\text { BRV (VP6) } \\
\text { probe }\end{array}$ & \multicolumn{3}{|c|}{ 5-FAM- accggctcatgataacttgatgggt- } \\
\hline
\end{tabular}

Viral RNA was extracted from the tissue by using AccuZol ${ }^{\mathrm{TM}}$ Total RNA extraction kit (Bioneer, Korea) and done according to company instructions. The extracted viral RNA and total RNA from samples were estimated by using Nanodrope spectrophotometry that used in the measurement of RNA \& evaluation of purity $\&$ absorbance. $260 / 280 \mathrm{~nm}$ of ratio 1.8 as pure RNA.

Statistical analysis : According to (12), the results were submitted to the statistical analysis for the calculation of infection rate and significant differences $(\mathrm{p}<0.050)$ among categorical variables ( sex, regions, age, and months) studied by using chi-square calculation method.

\section{Results}

The results of clinical study showed that there were fever up to $40^{\circ} \mathrm{C}$, serous watery nasal discharge, lacrimation, coughing, depression, increased of respiratory rate and abnormal breath sounds (loud, harsh sound, whistling or wheezing). Whereas the results of gross examination were congestion of tracheal and bronchial mucus membrane and maybe there was congestion and hemorrhage of the lungs. The results of direct ELISA test proved the occurrence of BPI-3V infection with percentage of $30.26 \%$, and the result also showed that there was no significant difference between male and female that recorded $25.9 \%$ and $32.2 \%$ respectively table(2). The infection rate by using ELISA test in relation to different study area showed that the percentage in Dagharah, Saniyaih, Sedeer, and Al-Diwaniya city were $(17.58 \%$, $35 \%, 40 \%$, and $34.78 \%$ ), respectively. BPIV3 infections were showed no significant differences between Sedeer $40 \%$, Saniyia $35 \%$, and Al-Diwaniya city $34.78 \%$ while significant difference found in Dagharah region $17.85 \%$ as compared with others table (3). Whereas there was a significant difference according to age groups 3 months3years, 3years-6 years, and 6years- 8 years which were $(48 \%, 23.68 \%$, and $21.73 \%)$, respectively. The age group (6 months -3 years) showed highest rate infection (48\%) as compared with age groups (3 years- 6 years) $(23.68 \%)$ and age group (6 years -8 years ) $(21.73 \%)$ table (4). There were a significant difference recording according to the months of the year, higher infection rate $(60 \%)$ recorded in cold months table (5). The results of reverse transcriptase real time quantitative polymerase chain reaction were $55.13 \%$ in cattle population as the increase sensitivity of this technique table(6).

Table (2): The infection rate according to the sex using direct ELISA technique

\begin{tabular}{|c|c|c|c|}
\hline sex & $\begin{array}{c}\text { Number of } \\
\text { Samples } \\
\text { Examined }\end{array}$ & $\begin{array}{c}\text { Number of } \\
\text { positive } \\
\text { Examined }\end{array}$ & $\begin{array}{c}\text { Infection } \\
\text { rate(\%) }\end{array}$ \\
\hline Male & 27 & 7 & $25.29 \mathrm{~A}$ \\
\hline Female & 59 & 19 & $32.2 \mathrm{~A}$ \\
\hline Total & 86 & 26 & 30.23 \\
\hline
\end{tabular}

Similar letters refers to the non-significant differences between sex at $(p<0.05)$

Table (3): The infection rate in relation to the region using direct ELISA technique.

\begin{tabular}{|c|c|c|c|}
\hline The region & $\begin{array}{c}\text { Number of } \\
\text { sample } \\
\text { examined }\end{array}$ & $\begin{array}{c}\text { Number } \\
\text { of positive } \\
\text { sample }\end{array}$ & $\begin{array}{c}\text { Infection } \\
\text { rate\% }\end{array}$ \\
\hline Dagharah & 28 & 5 & $17.85 \mathrm{~A}$ \\
\hline Saniyiah & 20 & 7 & $35 \mathrm{~B}$ \\
\hline Sedeer & 15 & 6 & $40 \mathrm{~B}$ \\
\hline $\begin{array}{c}\text { Al- } \\
\text { Diwaniya } \\
\text { city }\end{array}$ & 23 & 8 & $34.78 \mathrm{~B}$ \\
\hline Total & 86 & 26 & 30.23 \\
\hline
\end{tabular}

Similar letters refers to the non-significant differences among region while different letters refers to significant differences at $(p<0.05)$ 
Table(4): The infection rate in relation to the age using direct ELISA technique:

\begin{tabular}{|c|c|c|c|}
\hline Ages & $\begin{array}{c}\text { Number of } \\
\text { sample } \\
\text { examined }\end{array}$ & $\begin{array}{c}\text { Number } \\
\text { of } \\
\text { positive } \\
\text { sample }\end{array}$ & $\begin{array}{c}\text { Infection } \\
\text { rate\% }\end{array}$ \\
\hline $\begin{array}{c}6 \text { monthe- } \\
\text { 3 years }\end{array}$ & 25 & 12 & $48 \mathrm{~A}$ \\
\hline $\begin{array}{c}3 \text { years- } 6 \\
\text { years }\end{array}$ & 38 & 9 & $23.68 \mathrm{~B}$ \\
\hline $\begin{array}{c}\text { 6 years- } 8 \\
\text { years }\end{array}$ & 23 & 5 & $21.73 \mathrm{~B}$ \\
\hline Total & 86 & 26 & 30.23 \\
\hline
\end{tabular}

Similar letters refers to the non-significant differences among ages while different letters refers to significant differences at $(p<0.05)$

Table (6): Results of molecular test using Real- Time qPCR.

\begin{tabular}{|c|c|c|c|}
\hline $\begin{array}{c}\text { Samples } \\
\text { type }\end{array}$ & $\begin{array}{c}\text { Number of } \\
\text { sample } \\
\text { examined }\end{array}$ & $\begin{array}{c}\text { Number } \\
\text { of positive } \\
\text { sample }\end{array}$ & $\begin{array}{c}\text { Infection } \\
\text { rate\% }\end{array}$ \\
\hline Lung & 33 & 18 & $54.54 \mathrm{~A}$ \\
\hline Trachea & 33 & 20 & $60.60 \mathrm{~A}$ \\
\hline $\begin{array}{c}\text { Nasal } \\
\text { swab }\end{array}$ & 28 & 14 & $50 \mathrm{~A}$ \\
\hline Total & 94 & 52 & 55.13 \\
\hline
\end{tabular}

Similar letters refers to the non-significant differences among ages while different letters refers to significant differences at $(\mathbf{p}<0.05)$

Higher percentage recorded in tracheal tissue sample $60.60 \%$ as compare with lungs tissue and nasal swabs in percentage $54.54 \%$ and $50 \%$, respectively, and there was no

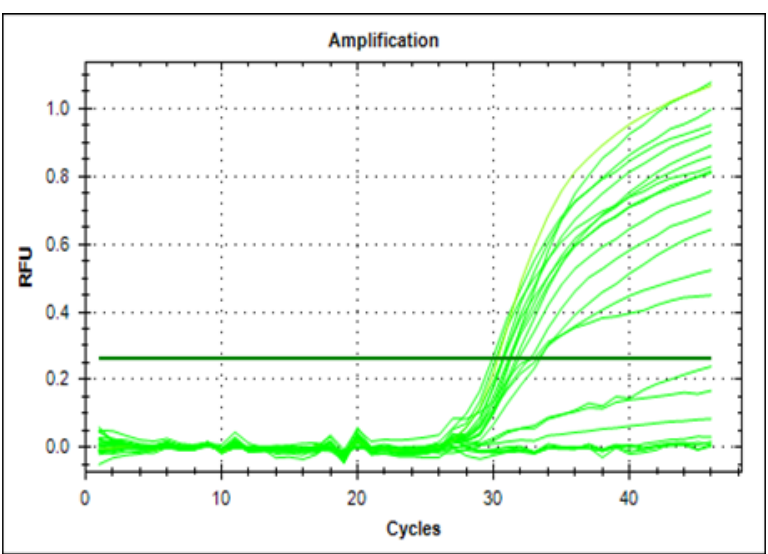

Fig. (2) Real-Time qPCR amplification plot of Bovine Parainfluenza virus 3 in nasal swab samples.
Table(5): Infection rate in relation to months using direct ELISA technique.

\begin{tabular}{|c|c|c|c|}
\hline $\begin{array}{c}\text { The } \\
\text { months }\end{array}$ & $\begin{array}{c}\text { Number of } \\
\text { examined } \\
\text { samples }\end{array}$ & $\begin{array}{c}\text { Number } \\
\text { of } \\
\text { positive } \\
\text { sample }\end{array}$ & $\begin{array}{c}\text { Infection } \\
\text { rate\% }\end{array}$ \\
\hline November & 21 & 6 & $28.57 \mathrm{AD}$ \\
\hline December & 15 & 9 & $60 \mathrm{~B}$ \\
\hline January & 10 & 1 & $10 \mathrm{C}$ \\
\hline February & 17 & 7 & $41.17 \mathrm{AB}$ \\
\hline March & 12 & 2 & $16.66 \mathrm{CD}$ \\
\hline April & 11 & 1 & $9.09 \mathrm{C}$ \\
\hline Total & 86 & 26 & 30.23 \\
\hline
\end{tabular}

Similar letters refers to the non-significant differences among months while different letters refers to significant differences at $(p<0.05)$.

significant difference has been recorded. Figure $(1,2,3)$.

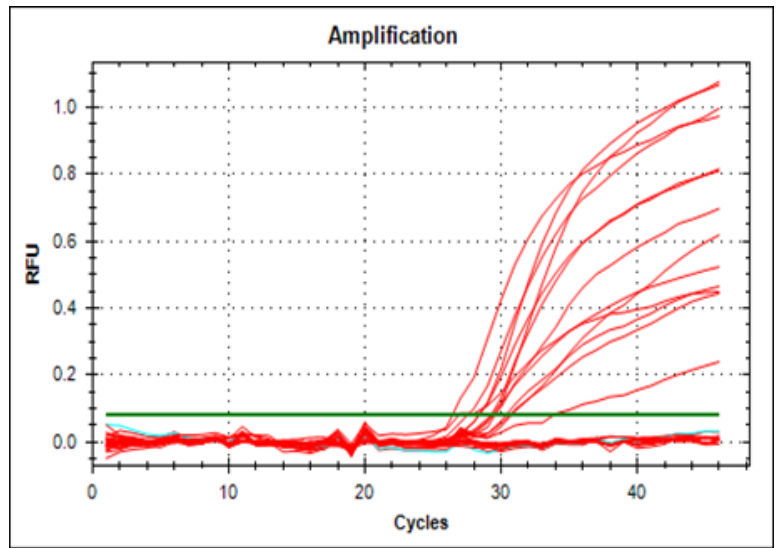

Fig. (1) Real-Time qPCR amplification plot of Bovine Parainfluenza virus in trachea samples

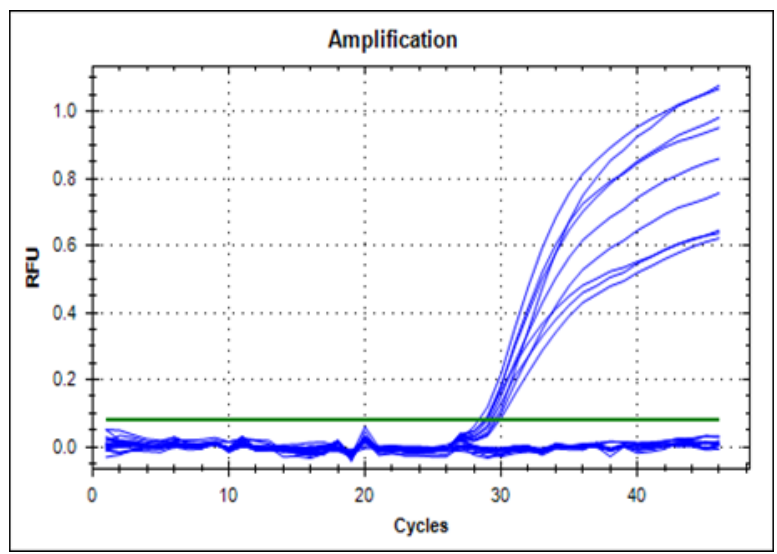

Fig. (3) Real-Time qPCR amplification plot of Bovine Parainfluenza virus 3 in lung samples. 


\section{Discussion}

The results of clinical study they were in agreement with $(13,14) .(15,16)$ recorded that clinical signs are anorexia, sneezing, the breathing may become stertorous, and often through the mouth, dyspnea, abnormal breath sounds and harsh dry cough but sometimes moist. And the results of gross examination were in agreement with $(15,17)$ whom found congestion in upper respiratory tract (trachea and bronchi) and lungs. Our result of direct ELISA test revealed high rate infection $30.23 \%$ that was indicate most cattle have been exposed to PI-3 infection and detection of the PI-3 virus in serum indicate that the disease was in viremic stage. These results were not in accordance with studies for detection of antibodies against PI-3 in Iran and Saudi Arabia by using indirect ELISA test that showed the seroprevalance of PIV-3 were $100 \%$ and $69.1 \%$, respectively $(18,19)$ and this may be due to presence of antibody against BPI-3 caused by previous infection and using of vaccine that may cause seroconversion for particular periods which may took months or years. High infection rate of PIV-3 recorded in this study is in agreement with the ubiquitous nature of the virus and with its worldwide distribution (20), may be because of no vaccines are used against this virus locally, and lack of control measures against this infection. And there was no influence of sex on the virus infection and that means the virus infection had been occurred in both sex as equal chance due to same management system of breeding and exposure the cattle to same stress factors like transportation for long distance, lack of nutrition, no vaccination and veterinarian care, and climatic change. \& regions difference could in part explained by

\section{References}

1-Wang LF, Collins PL, Fouchier R A M, Kurath G, Lamb R A, Randall R E, and Rima B K (2007). family Paramyxoviridae. In Virus taxonomy: Ninth report of the international committee on taxonomy of viruses. Edited by King AMQ, Lefkowitz E, Adams MJ. San Diego, California: Elsevier Academic Press:672-685. geographical nature of the regions. Variation of age groups infection were in agreement with (21) who found clinical disease is most common in calves with poor passive transfer or decayed maternal antibodies, and that BPIV-3 infection is often complicated by coinfection with other respiratory viruses and bacteria and is therefore an important component of enzootic pneumonia in calves and bovine respiratory disease complex in feedlot cattle. The significant difference recording according to the months of the year, was in accordance with (21). Who referred that winter season characterized by high occurrence rate of BPIV-3 due to rapid changes in weather, and close the air inlets that result in increased humidity, condensation of moister on walls and on calves, leading to wet conditions, and the reduction ventilation results in an increase in the concentration of droplet infection. Reverse transcriptase real time quantitative polymerase chain reaction results according to the sites of infection were not accordance with (22) who found that percentage of BPIV-3 infection in trachea, lung, and nasal swabs were $5.88 \%, 6.54 \%$, and $2.94 \%$, respectively. with (22) and that may be because of lack of vaccination program, inefficient veterinarian care, poor management factors, and exposure the animals to stress factors. There was no significant differences between the relationship of infections and site of the respiratory system, that indicated the virus can be attached and replicated in different site of epithelial cells of the respiratory system that in agreement with (6), who showed that the major site of replication is epithelial cells in the respiratory tract.

2-Sweat L R (1967). Isolation of myxovirus, parainfluenza 3 from cattle with respiratory disease. J. Am. vet. med. Ass. 156:172-177.

3-Assaf P R, Montpetit C, and Marsolais G (1983). Serology of bovine parainfluenza 3:comparson of the enzyme linked immunosorbent assay and heamagglutination inhibition.Can.Comp.Med.47:140-142 
4-Cusack P M, McMeniman N, and Lean I J (2003). The medicine and epidemiology of bovine respiratory disease in feedlots. Australian Vet. J., 81:480-487.

5-Ellis J A (2010). Bovine parainfluenza-3 virus. Vet. Clinic. North Am. Food Anim. Pract. 26(3):57593.

6-Ibu O J, Salihu E A, Abechi M A, ABA-Adulugba and Okewu M (2005). Activity of Bovine Parainfluenza type 3 virus in cattlein northern Negeria- A short communication. Sokoto J. of Vet. science. 6: 1-4.

7-Plummer P J, Rohrbach B W, Daugherty R A, Daugherty R A, Thomas K, V, Wilkes R P, Duggan F E, and Kennedy M A (2004). Effect of intranasal vaccination against bovine enteric corona virus on the occurrence of respiratory tract disease in a commercial back grounding feedlot. $J$. Am. Vet. Med. Assoc., 225:726-731.

8-Valarcher J F, and Hägglund S (2006). Viral respiratory infection in cattle. In: Proceedings of the 24th World Buiatrics Congress. Nice, France.

9-Kapil S, and Basaraba RJ (1997). Infectious Bovine Rhinotrachitis, Para-influenza-3, and Respiratory Corona virus. Vet. Clin. of N. Am. and F. Anil. Practice.13:455-469.

10-Hirsh D C, and Chung Zee Y (2002). Parainfluenza type 3, Vet. Micro. ledn. Blackwell Science Inc. U.S.A. pp: 403-410.

11-Sweat L R (1967). Isolation of myxovirus, parainfluenza 3 from cattle with respiratory disease. J. Am. vet. med. Ass.156:172-177.

12-Al-Rawi K (2000). Entrance to statistics. Ministry of higher education and scientific research in Iraq. University of Al-Mosul. Second Edition.
13-Dinter Z, and Morein D (1990). Virus infections in ruminants. New York: Elsevier Science Puplishers $B V$.

14-Ellis JA (2010). Bovine parainfluenza-3 virus. Vet. Clin. North Am. Food Anim. Pract. 26(3):575-93.

15-Andrews A H (2004). Calf respiratory diseases. In: Bovine medicine, Oxford, UK, pp. 239-248.

16-Yates W D G (1982). A review of infectious bovine rhinotrachitis, shipping fever pneumonia and viral-bacterial synergism in respiratory disease of cattle. Can. J. comp. Med. 46:225-263.

17-Ayroud M, Popp J D, and VanderKop A M (2000). Characterization of acute interstitial pneumonia in cattle in southern Alberta feed yards. Can. Vet. J .41:547-554.

18-Sakhaee E, Khalili M, and Kazeminia H (2009). Serological study of bovine viral respiratory disease in dairy herds in kerman province, Iran, Ira. J. of V. Res.10(1): 49-53.

19-Yousef M R, El Fatah M A, Ali S M, and Al-Blowi M H (2013). Seroprevalence of some bovine viral respiratory diseases among non-vaccinated cattle in Saudi Arabia. Veterinary World: 6 (1): 1-4.

20-Bryson D G (1990).Parainfluenza-3 virus in cattle. In: Virus infection in ruminants (Eds. Dinter Z, and Morin B). Elsevier Amsterdam. pp: 319-333.

21-Radostits OM, Gay CC, Hinchcliff KW, and Constable PD (2007). Vet. Med.10th edition. Elsevier limited U.S.A. pp 1338-1342.

22-Thonur L, Maly M, and Gilray J (2012).One-step multiplex real time RT-PCR for the detection of bovine respiratory syncytial virus, bovine herpesvirus 1 and bovine Parainfluenza virus 3. B.M.C. Veterinary Research, 8:37. 